\title{
Effect of Climatic Variability on Population Dynamics of Insect Pests and Natural Enemies in Linseed (Linum usitatissimum L.)
}

\author{
S. K. Sahoo* \\ Pulses and Oilseeds Research Station Government of West Bengal, Berhampore, Murshidabad, \\ West Bengal (742 101), India
}

\section{Article History}

Manuscript No. AR1516

Received in $9^{\text {th }}$ January, 2016

Received in revised form $30^{\text {th }}$ March, 2016

Accepted in final form $4^{\text {th }}$ April, 2016

\section{Correspondence to}

"E-mail: shyamalsahoo@yahoo.co.in

\section{Keywords}

Linseed, natural enemies, climatic factors, correlation, regression analysis

\begin{abstract}
The influence of climatic variability on the insect pests of linseed and their natural enemies were investigated during rabi seasons of the year 2011-12, 2012-13 and 2013-14 at Berhampore, West Bengal, India. During the course of investigation four insect pests namely bud fly, termite, thrips and jassids along with two natural enemies (lady beetle and spider) were noticed at various growth stages of linseed crop. The infestation due to bud fly, termite, thrips and jassids were recorded upto $41 \%$ bud damage, $18 \%$ cut, 9 thrips plant ${ }^{-1}$ and 4 jassids plant ${ }^{-1}$, respectively. Last week of February was most suited for multiplication of bud fly and thrips. Infestation of termite initiated during maturity stage of the crop with the maximum damage at $10^{\text {th }}$ Standard Meteorological Week when soil was dry and they attacked at the basal portion of the crop. The correlation worked out between insect pests and natural enemies with the weather parameters revealed significant positive correlation with the temperature but negatively correlated with relative humidity. It is revealed from the step wise regression equation that combined effect of all weather parameters had more influence on insect pests population and except maximum temperature none of the weather factor alone had much more effect on them. The combined influence of rainfall, temperature and relative humidity on bud fly, termite, thrips and jassids population increased with $\mathrm{R}^{2}$ value of $0.782,0.651,0.779$ and 0.857 , respectively.
\end{abstract}

\section{Introduction}

The population dynamics is the aspect of population ecology dealing with factors affecting changes in population densities. The seasonal effects of weather and ongoing changes in climatic conditions will directly lead to modifications in dispersal and development of insect species and the mechanisms through which they act upon the populations are of primary importance to the entomologists (Karuppaiah and Sujayanad, 2012).

Insects are a dominant component of agricultural ecosystems and affects crop production in many ways. Several species are key pests of agricultural and horticultural crops, reducing yields by direct damage or through the transmission of plant virus diseases. Others are significant enemies of pest species, and can be exploited as natural regulatory agents for managing the pest organisms. The insects are poikilothermic and sensitive to precipitation. They have a tendency to fluctuate as a result of their inherent characteristics, influenced by the environmental factors directly on their physiology and behaviour (Parmesan, 2007; Bale et al., 2002). The degree of influence of various environmental factors, determines the magnitude of an increase or a decrease in the number of an insect population. Knowledge of insect population dynamics is therefore essential for developing sustainable crop protection strategies and for safeguarding the health of agricultural environments. It is also required for interpreting and forecasting the response of different taxonomic groups to weather patterns varying on a daily basis, seasonally, or as a long-term consequence of global change.

Oilseeds occupy an important position in agriculture and industrial economy next to food grains in terms of area, production and value (Mukherji et al., 1999). Linseed (Linum usitatissimum L.) is an important rabi oilseed crop in India. It is grown for its fibre (fibre flax), or its seed oil (oil flax, seed flax or linseed) or for both purposes (dual purpose flax). It is highly nutritious and is a source of complete protein (all 8 essential amino acids), high order linolenic acid (source 
of Omega-3 and Omega-6 fatty acids which have immense nutritional or medicinal values on human body system), complex carbohydrates, vitamins and minerals. India is an important $(16 \%)$ linseed growing country in the world and it contributes $7 \%$ to the world linseed pool (Anonymous, 2011). In West Bengal the area under this crop was 4.315 thousand hectares and production 1.554 thousand tones with the productivity of $360 \mathrm{~kg} \mathrm{ha}^{-1}$ during 2014-15 (Anonymous, 2015). The productivity is very low as compared to the average world yield of $1006 \mathrm{~kg} \mathrm{ha}^{-1}$ (Anonymous, 2011).

Among the various factors responsible for low yield of linseed, insect pests are highly destructive causing serious damage and are responsible for lowering the yield of linseed crop (Malik, 2006). Due to the variation in agro-climatic condition of different regions, these insect pests show varying trends in their incidence and also in nature and extent of damage to the crop. Hence, a region oriented study is necessary, as it would help in combating the problem and boosting the production. It is, therefore, imperative to study the population fluctuation of the crop pest and natural enemies in relation to weather parameters that largely direct the activity of insect pest and natural enemies. Therefore, the present investigation was carried out to study the population build up of insect pests and its natural enemies in the linseed crop in relation to the abiotic factors.

\section{Materials and Methods}

The experiment was conducted for three consecutive years during rabi season of 2011-12, 2012-13, 2013-14 at the Pulses and Oilseeds Research Station, Government of West Bengal, Berhampore, Murshidabad, West Bengal, India (situated at $24^{\circ}$ North latitude and $88^{\circ}$ East longitude). Linseed variety 'Neelum' was sown during last week of November in each year in the plot, having the area of $7 \times 6 \mathrm{~m}^{2}$ with three replications and distance from row to row and plant to plant were maintained at $30 \mathrm{~cm}$ and $8-10 \mathrm{~cm}$, respectively. Full quantity of the recommended fertilizers $\left(50: 25: 25 \mathrm{~kg} \mathrm{ha}^{-1}\right.$ NPK) except half of the nitrogen was applied before seeding and remaining half was given after irrigation (20 DAS). The experimental site was kept free from any pesticide application. No chemical treatment and other insect pest management techniques were adopted in the selected linseed fields. All other recommended agronomic practices were followed to raise the crop.

The incidence of insect pests and natural enemies were recorded from 7 days after germination up to harvest of the crop at weekly interval. Per cent bud infestation by bud fly, population of thrips in the flower \& unfolded leaflet, per cent crop cut at basal portion by termite and population of leaf hopper, lady beetle \& spider were recorded from 10 randomly selected plants in each plot. Weekly data on weather parameters were collected from Meteorological Observatory, Pulses and Oilseeds Research Farm, Government of West Bengal, Berhampore, West Bengal. The relationship between the incidence of insect pests and natural enemies with the weather parameters were examined by the correlation calculation and regression analysis using Microsoft Excel 2007 software.

\section{Results and Discussion}

\subsection{Bud fly}

During the course of investigation bud fly was recorded as major pest (Table 1) with of $41 \%$ bud damage. Among all the weather parameters, maximum temperature showed significant positive correlation $\left(\mathrm{r}=0.731^{*}\right)$ with the bud fly infestation (Table 2). It was also revealed from the table 2 that maximum and minimum relative humidity had significant negative effect on the damage of linseed bud fly. This might be because of the rate of development of pests will enable a more rapid response to a change in temperature (Karuppaiah and Sujayanad, 2012). The infestation of bud fly recorded over three years of experimentation were presented in the Figure 1, which showed the bud fly infestation increased with the age of the crop which was maximum during $10^{\text {th }}$ standard meteorological week (5-1 $11^{\text {th }}$ March).

The influences of rainfall, temperature and relative humidity on population build up of bud fly were worked out through step down regression analysis. It was observed that the

\begin{tabular}{|c|c|c|c|c|c|}
\hline Sl. no. & Common name & Scientific name & Order & Family & Status \\
\hline 1. & Bud fly & Dasyneura lini Barness & Diptera & Cecidomyiidae & Pest \\
\hline 2. & Termite & Odontotermes spp. & Isoptera & Termitidae & Pest \\
\hline 3. & Thrips & Caliothrips indicus Bugnall & Thysenoptera & Thripidae & Pest \\
\hline 4. & Leaf hopper & Empoasca kerri Pruthi & Hemiptera & Cicadellidae & Pest \\
\hline 5. & Lady beetle & Coccinella septempunctata $\mathrm{L}$. & Coleoptera & Coccinellidae & Predator \\
\hline 6. & Lynx Spider & $\begin{array}{c}\text { Menochilus sexmaculatus Fab. } \\
\text { Oxypes javanus Thorell }\end{array}$ & Araneae & Oxyopidae & Predator \\
\hline
\end{tabular}


Table 2: Correlation studies between insect pests of linseed and their natural enemies with weather parameters in West Bengal

\begin{tabular}{lccccc}
\hline Insect pests and Natural enemies & \multicolumn{5}{c}{ Correlation value $(\mathrm{r})$} \\
\cline { 2 - 5 } & Rainfall $(\mathrm{mm})$ & Tmax. $\left({ }^{\circ} \mathrm{C}\right)$ & Tmin. $\left({ }^{\circ} \mathrm{C}\right)$ & RHmax. $(\%)$ & RHmin. $(\%)$ \\
\cline { 2 - 5 } Bud fly & -0.138 & $0.731^{* *}$ & 0.561 & $-0.825^{* *}$ & $-0.681^{*}$ \\
Termite & -0.117 & $0.656^{*}$ & 0.418 & $-0.724^{* *}$ & -0.554 \\
Thrips & -0.153 & $0.806^{* *}$ & $0.622^{*}$ & $-0.765^{* *}$ & $-0.711^{* *}$ \\
Leaf hopper & -0.274 & $0.722^{* *}$ & 0.457 & $-0.768^{* *}$ & -0.522 \\
Lady bird beetle & -0.271 & $0.839^{* *}$ & $0.581^{*}$ & $-0.805^{* *}$ & $-0.657^{*}$ \\
Spider & -0.396 & $0.884^{* *}$ & $0.797^{* *}$ & $-0.672^{*}$ & $-0.604^{*}$ \\
\hline
\end{tabular}

${ }^{* *}$ Significant at $(p=0.05) ; \mathrm{df}=10 ;{ }^{*}$ Significant at $(p=0.01)$

combined influence of these weather parameters had more influence on infestation of bud fly $\left(\mathrm{R}^{2}=0.782\right)$ than the single weather parameter as the $\mathrm{R}^{2}$ value was only 0.019 (Table 3 ). The combined effect of rainfall and maximum temperature with $\mathrm{R}^{2}$ value of 0.535 and when maximum temperature was deleted the $\mathrm{R}^{2}$ value comes down to 0.019 . This shows that maximum temperature have $51.6 \%$ influences. Similar observations were also reported by Sahoo (2013) and Choudhury and Pal (2009).

\subsection{Termite}

Population of termite recorded over three years. Figure 1 showed their infestation initiated during maturity stage of the crop with the maximum damage of $18 \%$ at $10^{\text {th }}$ SMW (5-11 $1^{\text {th }}$ March). During that stage soil condition was dry and they attacked at the basal portion of the crop, as a result production of linseed was hampered. Similarly, Pal (2004) reported from West Bengal that the insect prefers to live in soil with less moisture and to eat upon more woody tissue. Correlation studies of termite infestation with the weather parameters showed significant positive correlation with the maximum temperature $\left(\mathrm{r}=0.656^{*}\right)$. It is also revealed from the table 2 that among all the weather parameters, maximum relative humidity had significant negative correlation on the termite infestation. From regression analysis it is found that the combined effect of rainfall and maximum temperature had $43.1 \%$ influences on termite infestation whereas only maximum temperature had $41.8 \%$ influence (Table 3 ).

\subsection{Thrips}

The thrips population also exhibited significantly maximum positive correlation with the maximum temperature $(\mathrm{r}=$ $0.806^{*}$ ) but significant negative correlation with relative humidity (maximum and minimum). The populations of thrips recorded over three of experimentation showed their incidence throughout the crop growing period with the peak population during $11^{\text {th }}$ SMW (12-18 ${ }^{\text {th }}$ March). Like other insects it was observed that the combined effect of weather parameters on the population build up of thrips had more influence $\left(\mathrm{R}^{2}=0.779\right)$ than a single weather parameter with $\mathrm{R}^{2}$ value of 0.023 (Table 3 ). The results of the present studies are in accordance with Humayun (2008), who reported that all the weather parameters combined together had a significant effect on thrips population fluctuation.

\subsection{Leaf hopper}

Population of leaf hopper was found throughout the crop season moderately with maximum level (4 jassids plant $\left.{ }^{-1}\right)$ during $10^{\text {th }}$ SMW (Figure 1). Correlation studies between population of jassids and weather parameters revealed significant positive correlation with maximum temperature but relative humidity had significantly negative correlation. Similarly Chundawat and Ameta (2011) reported the significant negative correlation between jassid population and relative humidity. Leaf hopper population also highly influenced by the combined effects of all the weather parameters than a single weather parameter except maximum temperature alone had $47.2 \%$ influence (Table 3 ).

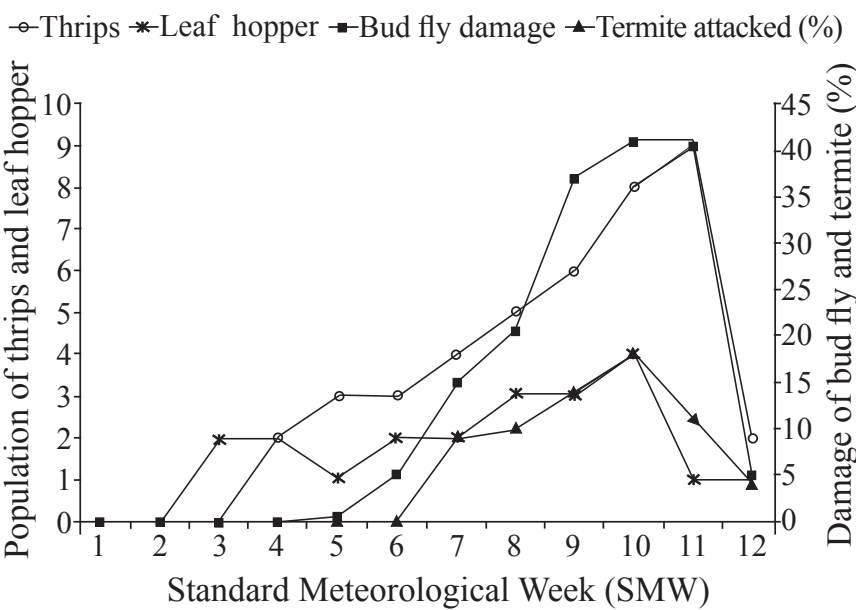

Figure 1: Population incidence of different insects pests of linseed in West Bengal 


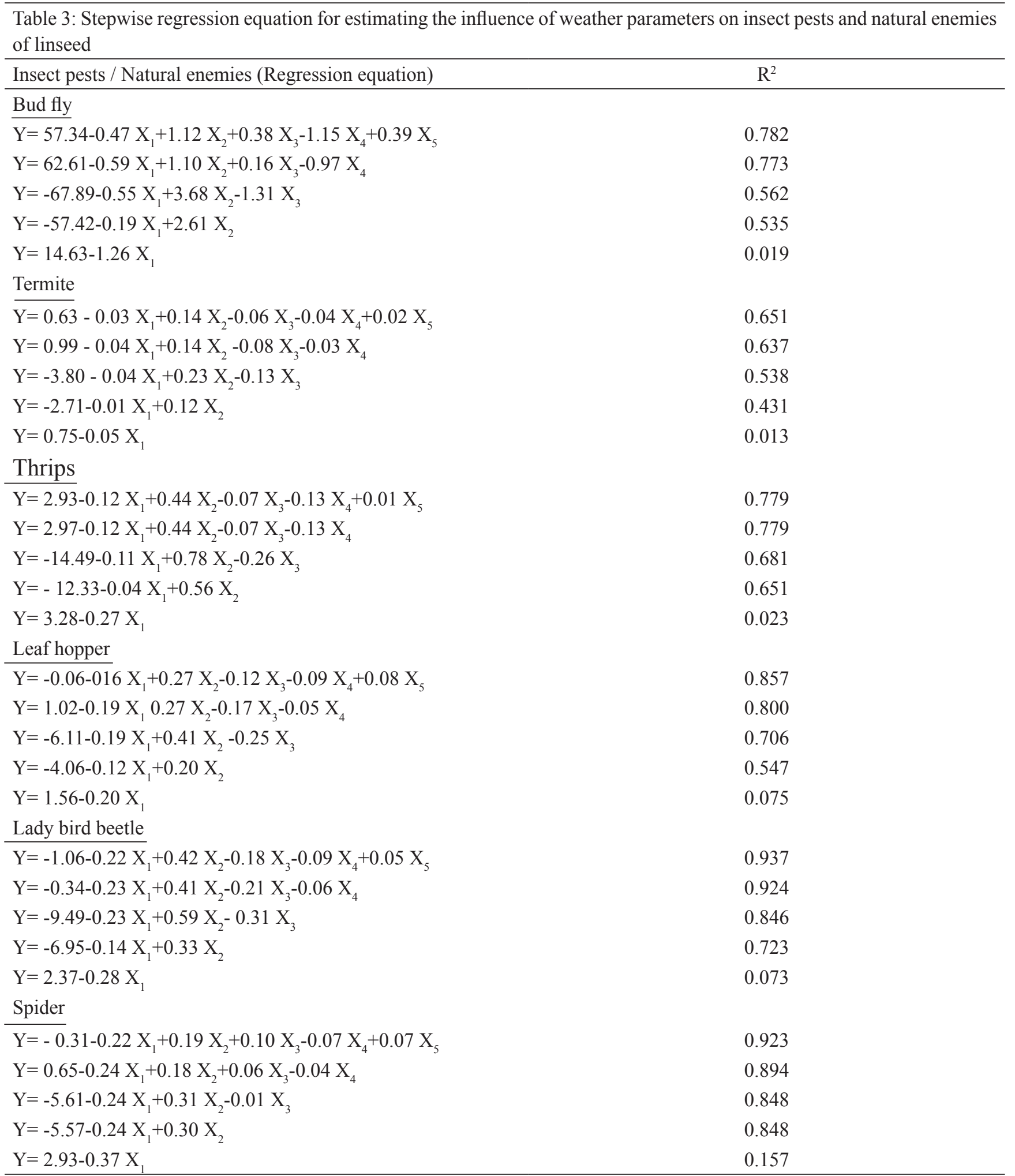

$\mathrm{X}_{1}$ : Rainfall (mm); $\mathrm{X}_{2}$ : Tmax. $\left({ }^{\circ} \mathrm{C}\right) ; \mathrm{X}_{3}$ : Tmin. $\left({ }^{\circ} \mathrm{C}\right) ; \mathrm{X}_{4}$ : RHmax. (\%); $\mathrm{X}_{5}$ : RHmin. (\%)

\subsection{Lady bird beetle and spider}

Two species of lady beetle and Spider were noticed as potential predator of the pests of linseed during the period of investigation (Table 1). In case of correlation studies for lady bird beetle and predatory spider, among all the weather parameters maximum temperature showed maximum value 
$\left(\mathrm{r}=0.839^{*}, 0.884^{*}\right)$, may be due to among the various weather factors, temperature cause the direct effect on their growth and development of the insect. Similarly, Dhaka and Pareek (2007) observed significant positive effect of temperature on population of spider from Rajasthan. It is revealed from the Table 3 that abiotic factors shares $93.7 \%$ and $92.3 \%$ impact on lady beetle and spider population, respectively.

\section{Conclusion}

Last week of February was most suited for multiplication of bud fly and thrips. The correlation study revealed significant values in most of the cases and all the insect pests \& natural enemies had significantly positive correlation with the temperature. From the step wise regression equation it may be concluded that combined effect of all weather parameters had more influence on insect population and except maximum temperature none of the weather factor alone had much more influence on them.

\section{References}

Anonymous, 2011. AICRP on linseed. In: Project Coordinator's Report, Annual Research Workers' Group meeting of AICRP on Linseed held at Directorate of Oilseeds Research, Hyderabad, Andhra Pradesh on August 27-29, 2011.

Anonymous, 2015. Estimates of area and production of principle crops in West Bengal. Evaluation Wing, Directorate of Agriculture, Government of West Bengal, Kolkata, 98.

Bale, J.S.B., Masters, G.J., Hodkinson, I.D., Awmack, C., Bezemer, T.M., Brown, V.K., Butterfield, J., Buse, A., Coulson, J.C., Farrar, J., Good, J.E.G., Harrington, R., Hartley, S., Jones, T.H., Lindroth, R.L., Press, M.C., Symrnioudis, I., Watt, A.D., Whittarker, J.B., 2002. Herbivory in global climate change research: direct effects of raising temperature on insect herbivores. Global Change Biology 8, 1-16.

Choudhury, S., Pal, S., 2009. Population dynamics of mustard aphid on different brassica cultivars under terai agroecological condition of West Bengal. The Journal of
Plant Protection Sciences 1(1), 83-86.

Chundawat, A.S., Ameta, O.P., 2011. Incidence of sucking insect pests of okra in relation to weather parameters. Indian Journal of Applied Entomology 25(1), 36-38.

Dhaka, S.R., Pareek, B.L., 2007. Seasonal incidence of natural enemies of key insect pests of cotton and their relationship with weather parameters. Journal of Plant Protection Research 47(4), 417-423.

Humayun, S.M.A., 2008. Studies on seasonal incidence of key pests of linseed and management strategies for linseed bud fly, Dasyneura lini Barnes (Diptera; Cecidomyiidae) at Raipur. In: Abstract of IGKV Thesis (T-2157), Nehru Library, Indira Gandhi Krishi Viswavidyalaya, Raipur, Chhattisgarh, 21.

Karuppaiah, V., Sujayanad, G.K., 2012. Impact of climate change on population dynamics of insect pests. World Journal of Agricultural Science 8(3), 240-246.

Malik, Y.P., 2006. Yield losses due to bud fly, Dasyneura lini Barnes in linseed. Journal of Oilseeds Research 23(2), 363.

Mandal, B.K., Bashar, K., Howlader, A.J. and Rahman, K.M.Z., 2010. Incidence of termite infestation to tree species in Jahangirnagar University Campus, Bangladesh. Bangladesh Journal of Life Science 22(7), 7-15.

Mukherji, K.G., Dubey, O.P., Upadhyaya, R., 1999. Insect pests of linseed. In: IPM system in agriculture (Oilseeds crops). Aditya Book Pvt. Ltd., 250-263.

Pal, P.K., 2004. Seasonal diversity with incidence and damage of insect pests in groundnut under red and laterite zone of West Bengal. Environment \& Ecology 22(3), 565-570.

Parmesan, C., 2007. Influence of species, latitudes and methodologies on estimates of phonological response to global warming. Global Change Biology 13, 1860-1872.

Sahoo, S.K., 2013. Population dynamics of mustard aphid, Lipaphis erysimi Kaltenbach (Hemiptera: Aphididae) on brassica germplasm. Indian Journal of Entomology 75(1), 9-14. 